\title{
Effect of different Nitrogen levels and Bio-fertilizers on yield and economics of feed barley
}

\author{
Neelam $^{1}$, Bhagat Singh ${ }^{1}$, Anil Khippal ${ }^{2}$, Mukesh $^{1}$ and Satpal ${ }^{1}$ \\ ${ }^{1}$ CCS Haryana Agricultural University,Hisar, 125004 \\ ${ }^{2}$ ICAR Indian Institute of Wheat and Barley Research, Karnal
}

\section{Article history}

Received: 30 Oct., 2018

Revised : 10 Dec., 2018

Accepted: 14 Dec., 2018

\section{Citation}

Neelam, B Singh, A Khippal, Mukesh and Satpal. 2018. Effect of different Nitrogen levels and Bio-fertilizers on yield and economics of feed barley. Wheat and Barley Research 10(3): 214-218. doi.org/10.25174/2249$4065 / 2018 / 84510$

\section{*Corresponding author}

Email: anil.khippal@icar.gov.in

(C) Society for Advancement of Wheat and Barley Research

\begin{abstract}
The field experiment was carried out during the Rabi season of 2015-16 and 2016-17 at CCS Haryana Agricultural University, Hisar. It was laid out in split plot design replicated thrice with three nitrogen levels (50, 75 and 100 percent of $R D N$ ) in main plots and five different biofertilizers alone or in combination (control, Azotobacter, Azotobacter + PSB, PSB and Biomixie Azotobacter + PSB + Azospirillum) in sub plots. Based on the research investigation, it was found that increasing levels of nitrogen and biofertilizers had significant effect on yield and yield attributing characters. The grain yield was affected significantly as the level of nitrogen increased from 50 to 100 percent. Highest grain yield and biological yield of $52.29 \mathrm{qha}^{-1}$ and $124.50 \mathrm{qha}^{-1}$ were recorded with the application of $100 \% \mathrm{RDN}$, which were significantly higher over lower doses of nitrogen. The maximum number of effective tillers $\mathbf{m}^{-2}$ (413), grains per ear head (50.91) and 1000-grains weight (43.84 g) were also found maximum at $100 \%$ RDN. Maximum Net returns (45732) and $\mathrm{B}: \mathrm{C}$ ratio $(2.40)$ were achieved when $100 \% \mathrm{RDN}$ was applied. Among different bio-fertilizers, Biomix recorded significantly higher yield attributes (effective tillers $m-2$, number of grains per spike and test weight). Grain and biological yield of $51.32 \mathrm{q} \mathrm{ha}^{-1}$ and $120.01 \mathrm{q}$ $\mathrm{ha}^{-1}$, respectively were recorded under Biomix, which were at par with Azotobacter + PSB treatment. Highest net returns of 41897 and B:C ratio of 2.28 were obtained with the application of Biomix in barley crop.
\end{abstract}

Keywords: Barley, Bio-fertilizers, Nitrogen levels, Grain yield and Economics

\section{Introduction}

Barley (Hordeum vulgare) is the world's $4^{\text {th }}$ most essential cereal crop after wheat, rice and maize with a share of about $7 \%$ of the global cereals production and $15 \%$ of coarse grains consumption. Barley is grown throughout the temperate, tropical and subtropical regions of the world and can be successfully grown in adverse climatic conditions of drought, salinity and alkalinity due to its wide adaptability. In India it is mainly grown as a rainfed crop in problematic, marginal and resource poor soils except some malt barley under contract farming. It is a rabicereal grain crop, which usually used as a food for human beings and feed for animals. For malting, both the two-row and six-row cultivars are used. Barley is superior to wheat as both grains and straw are highly digestible due to the absence of gluten. In the world, barley crop covers an area of $49.29 \mathrm{~m}$ ha with production $147.16 \mathrm{~m}$ t and productivity of $2990 \mathrm{~kg} \mathrm{ha}^{-1}$, respectively during 2016-17 (Anonymous, 2018). In India, barley is mainly grown in Rajasthan, Uttar Pradesh, Punjab and Haryana besides the minor quantities at other places with the area of 0.59 million hectares, 1.5 million tons production and $2550 \mathrm{~kg} / \mathrm{ha}$ productivity in the year 2015-16 (Anonymous, 2016). With an area of 48.0 thousand hectare, production 167.0 thousand tones and average productivity $3480 \mathrm{~kg} / \mathrm{ha}$ in Haryana, barley 
is grown mainly in the South-Western zone (Anonymous, 2014-15). India supports about 512 million livestock population and there is tremendous pressure on timely availability of feed and fodder for the livestock (Singh $e t$ al., 2016). India faces a net deficit of $61.1 \%$ green fodder, $21.9 \%$ dry crop residues and 64\% feed (Kumar et al., 2012). Since long, only chemical fertilizers are in use tremendously to raise crops which are quite expensive, so the small and marginal farmers are unable to afford chemical fertilizers in required quantity. Moreover, consistent and sole use of inorganic fertilizers has arisen as innumerable problems for example micronutrient deficiency, nutrient imbalance in case of plant and soil system, pest attack, environmental degeneration and degradation of soil health. Now, it is indeed to promote the integrated use of organic manure, bio-fertilizers with chemical fertilizers to minimize the dependence on inorganic fertilizers alone. Bio-fertilizer usually contains microorganisms having specific function such as Azospirillum to fix $\mathrm{N}_{2}$ and Phosphate solubilizing bacteria to solubilize unavailable Phosphorous from the soil and fertilizer to be available to the plants (Saraswati \& Sumarno, 2008). Inoculation of bacteria has synergistic and additive effects on plant growth besides reducing the cost of cultivation, reduced leaching of $\mathrm{NO}_{3}-\mathrm{N}$ to ground water as well as reduced emission of $\mathrm{N}_{2} \mathrm{O}$ greenhouse gas, the global warming effect of which is 300 times more than $\mathrm{CO}_{2}$ (Kennedy et al., 2004). The ability of these bacteria to contribute in crops yields is only partly a result of biological $\mathrm{N}_{2}$ fixation. Due to prolonged cultivation of crops with recommended dose of inorganic fertilizers alone, the productivity of soils has gone down and time has come to figure out the judicious and well matched level of fertilizers with these inoculations in case of barley production. Keeping the above facts in view, present study was conducted to assess the effect of nitrogen levels and different bio-fertilizers alone or in combination on feed barley.

\section{Material and methods}

A field experiment was carried out during the Rabi season of 2015-16 and 2016-17 at Research Farm, Wheat \& Barley Section, Dept. of Genetics \& Plant breeding, CCS HAU, Hisar, Haryana (India) situated at $29^{\circ} 10^{\prime} \mathrm{N}$ latitude and $75^{\circ} 46^{\prime} \mathrm{E}$ longitude at an elevation of 215.2 $\mathrm{m}$ above mean sea level. A composite sample of soil was collected from the experimental site before sowing and was analysed for various soil parameters. The soil was sandy loam in texture, having $\mathrm{pH}$ of 7.8 , O.C. of $0.48 \%$ (low), available P, $14 \mathrm{~kg} /$ ha (medium) and available K, 220 $\mathrm{kg} / \mathrm{ha}$ (medium). The experiment was laid out in split plot design replicated thrice with three nitrogen levels (50, 75 and 100 percent of RDN) in main plots and five different alone or in combination (control, Azotobacter, Azotobacter + PSB, PSB and Biomix) in sub-plots. The recommended dose of nitrogen (RDN), $\mathrm{P}$ and $\mathrm{K}$ were 60,30 and $20 \mathrm{~kg}$ /ha respectively. To carry out the experiment the land preparation operation viz pre sowing irrigation, plowing and leveling were done. Half dose of nitrogen and full dose of phosphorous were applied as basal dose and another half dose of nitrogen was top-dressed at first irrigation. Feed barley variety BH 946 was sown at row spacing $22 \mathrm{~cm}$ manually on $11^{\text {th }}$ November, 2015 during first year and on $13^{\text {th }}$ November, 2016 during second year. Yield attributing parameters were recorded at the time of harvest. Five plants were selected randomly from each treatment to record the observations of yield attributing characters. The crop was harvested on $9^{\text {th }}$ April, 2016 and $15^{\text {th }}$ April, 2017 during first and second year, respectively.

The harvest index $(\mathrm{HI})$ was calculated using the formula: $\mathrm{HI}=($ Economical yield / Biological yield $) * 100$.

The cost of cultivation, net returns and $\mathrm{B}: \mathrm{C}$ ratio were calculated using prevailing prices of inputs and output. The data were analyzed using appropriate analysis of variance (ANOVA). OPSTAT software was used to carry out statistical analysis.

\section{Results and discussion}

Data pertaining to grain yield of barley is presented in Table 1. A perusal of the data under nitrogen levels and different bio-fertilizers alone or in combination reveal that increasing levels of nitrogen resulted in significant increase in grain yield of barley. Highest grain yield was recorded with the application of $100 \% \mathrm{RDN}$ ( $52.29 \mathrm{q} / \mathrm{ha}$ ), which was significantly superior over the lower $\mathrm{N}$ levels. Similar trend was observed in case of biological yield, highest biological yield was recorded under 100\% RDN (124.50 qha-1), which was significantly superior over other treatments. Furthermore, grain yield of $100 \%$ RDN treatment was $6.87 \%$ and $26.51 \%$ higher over $75 \% \mathrm{RDN}$ and $50 \% \mathrm{RDN}$, respectively. It might be due better yield attributing characters of barley which were also significantly higher with higher levels of fertilizer application. Behera and Rautaray (2010) also recorded maximum grain and straw yields under recommended fertilizer dose (100\% NPK) than under $50 \%$ NPK. This increase in the yield of barley may be attributed to the increased plant height, leaf area index and higher dry matter partitioning with 100\% RDN. Corroborative results for grain, straw and biological yield were also reported by Singh et al. (2013), Javaheri et al. 
(2014), Nega et al. (2015) and Kumar et al. (2017). Harvest Index was also recorded maximum with the application of $100 \%$ RDN (42.0). Yield attributes viz., number of, effective tillers per $\mathrm{m}^{-2}$, grains per earhead and test weight were favorably influenced by increasing nitrogen levels. Application of $100 \%$ RDN produced significantly more number of effective tillers per $\mathrm{m}^{2}$ (413) than $50 \% \mathrm{RDN}$. Number of grains per earhead and test weight were also found maximum under $100 \% \mathrm{RDN}$ with the values of 50.91 and $43.84 \mathrm{~g}$, respectively, which were significantly superior over the application of 50\% RDN. Better yield attributes of barley due to application of higher nitrogen levels might be due to better growth parameters with the increasing level of nitrogen application. These findings of yield attributes substantiate the results reported by Chaturvedi and Chandel (2005), Chakrawarti and
Kushwaha (2006), Singh et al. (2013) and Alghabari and Al-Solaimani (2015). Cost of cultivation of barley increased with the increasing levels of fertilizers. Highest net returns and benefit cost ratio was recorded with application of $100 \%$ RDN (45732 and 2.40). Benefit cost ratio of barley increases significantly with increase in fertilizer levels from 50 to $100 \% \mathrm{RDN}$ (Table 2). The higher returns were obtained with increasing fertilizer levels are mainly due to higher yields recorded with higher nitrogen levels. These results are in accordance with those of Chakrawarti and Kushwaha (2006) who reported that the higher net profit was obtained with the application of $90 \mathrm{~kg} \mathrm{~N} \mathrm{ha}^{-1}$ compared to $60,30 \mathrm{~kg} \mathrm{~N} \mathrm{ha}^{-1}$ and control treatments. A perusal of data presented in Table 1 revealed that, among different bio-fertilizers alone or in combination, seed inoculation with Biomix resulted in significantly

Table1. Effect of different nitrogen levels and bio-fertilizers on yield and yield attributes of barley (pooled data of 2015-16 and 2016-17)

\begin{tabular}{|c|c|c|c|c|c|c|}
\hline Treatments & Effective tillers/m2 & Grains/earhead & $\begin{array}{c}\text { Test weight } \\
(\mathrm{g})\end{array}$ & $\begin{array}{c}\text { Grain yield } \\
(\mathrm{q} / \mathrm{ha})\end{array}$ & $\begin{array}{c}\text { Biological } \\
\text { yield (q/ha) }\end{array}$ & $\begin{array}{c}\text { Harvest } \\
\text { Index }(\%) \\
\end{array}$ \\
\hline \multicolumn{7}{|l|}{ Nitrogen levels } \\
\hline $50 \% \mathrm{RDN}$ & 372 & 47.08 & 42.39 & 41.33 & 103.08 & 40.09 \\
\hline $75 \% \mathrm{RDN}$ & 402 & 49.37 & 43.27 & 48.93 & 117.75 & 41.55 \\
\hline $100 \% \mathrm{RDN}$ & 413 & 50.91 & 43.84 & 52.29 & 124.5 & 42 \\
\hline SEm \pm & 3 & 0.16 & 0.22 & 0.48 & 1.22 & - \\
\hline $\mathrm{CD}(\mathrm{P}=0.05)$ & 13 & 0.64 & 0.89 & 1.93 & 4.91 & - \\
\hline \multicolumn{7}{|l|}{ Biofertilizers } \\
\hline Control & 382 & 47.21 & 42.29 & 45.53 & 110.94 & 41.04 \\
\hline Azotobacter & 392 & 47.91 & 42.97 & 46.88 & 113.34 & 41.36 \\
\hline Azotobacter + PSB & 404 & 50.83 & 43.51 & 48.9 & 117.49 & 41.62 \\
\hline PSB & 394 & 48.32 & 43.13 & 47.01 & 113.78 & 41.32 \\
\hline BIOMIX & 406 & 51.32 & 43.95 & 49.27 & 120.01 & 41.05 \\
\hline $\mathrm{SEm} \pm$ & 4 & 0.51 & 0.23 & 0.54 & 0.97 & - \\
\hline $\mathrm{CD}(\mathrm{P}=0.05)$ & 11 & 1.51 & 0.68 & 1.57 & 2.85 & - \\
\hline
\end{tabular}

Table 2. Effect of different nitrogen levels and bio-fertilizers on economics of barley (Pooled data of 2015-16 and 2016-17)

\begin{tabular}{lccc}
\hline Treatments & $\begin{array}{c}\text { Cost of } \\
\text { cultivation (₹) }\end{array}$ & $\begin{array}{c}\text { Net } \\
\text { returns (₹) }\end{array}$ & $\begin{array}{c}\text { B:C } \\
\text { ratio }\end{array}$ \\
\hline Nitrogen levels & & & \\
$50 \%$ RDN & 32403 & 30,581 & 1.94 \\
$75 \%$ RDN & 32595 & 41,110 & 2.26 \\
100\% RDN & 32761 & 45,732 & 2.4 \\
Biofertilizers & & & \\
Control & 32506 & 36346 & 2.12 \\
Azotobacter & 32606 & 38111 & 2.17 \\
Azotobacter + PSB & 32606 & 41013 & 2.26 \\
PSB & 32606 & 38337 & 2.18 \\
Biomix & 32606 & 41897 & 2.28 \\
\hline
\end{tabular}

higher grain yield, which was at par with the Azotobacter + PSB treatment. Seed inoculation with Biomix resulted in grain yield of $49.27 \mathrm{qha}^{-1}$ and biological yield of 120.01 $\mathrm{qha}^{-1}$. Seed inoculation with Rhizobium, phosphorus solubilizing bacteria and organic amendment increased seed production of the crop (Panwar et al ., 2006). Lowest value for grain and biological yield was recorded in control (45.53 and $110.94 \mathrm{qha}^{-1}$, respectively). However, the difference in grain yield and biological yield of barley in seed inoculation with Azotobacter and PSB alone were not significant with the control. Seed inoculation with Biomix resulted in 4.80, 5.09 and 8.21 \% higher grain yield over PSB, Azotobacter and control treatment, respectively. Inoculation of barley with different combination of biofertilizers has synergic and additive effects on yield as they increase the fertilizer use efficiency as well as soil fertility by promoting soil microbial activities, narrow down $\mathrm{C}: \mathrm{N}$ ratio, decline in bulk density and increase in water holding capacity at low moisture levels. Similar findings were also reported by, Nisha et al. (2007), Behera and Rautaray (2010), Yadav et al. (2011), Shirinzadeh et al. 
(2013), Yadav et al. (2014) and Diman and Dubey (2017). Seed inoculation with Biomix recorded significantly higher value for effective tillers per $\mathrm{m}^{2}$ i.e. 406 , which was found significantly higher than the control and inoculation of bio-fertilizers alone but at par with the seed inoculation of Azotobacter and PSB in combination. Number of grains per earhead (51.32)and test weight (43.95 g) with Biomix inoculation were numerically at par with Azotobacter + PSB but significantly better over other treatments. The reason for increased yield attributes of barley might be due to release of growth hormones by various biofertilizers. Similar findings for yield attributes were reported by Singh and Prasad (2011), Thalooth et al. (2012), Shirinzadeh $e t$ al. (2013) and Diman and Dubey (2017). Among different combination of bio-fertilizers, seed inoculation with Biomix resulted in significantly higher net returns and benefit cost ratio which might be ascribed to the higher grain and biological yield recorded due to seed inoculation with Biomix. Seed inoculation with Biomix resulted in net returns of 41897 (Table 2). Least value for net returns was reported in untreatedtreatment (36346). Seed inoculation with Biomixresulted in highest benefit cost ratio (2.28). Higher B:C ratio in Biomix treatment is because of very less increase in cost of cultivation as compared to the control. Similar results were reported by Yadav et al. (2014).

\section{Conclusion}

On the basis of two year study during 2015-16 and 201617 , it can be concluded that increasing nitrogen doses increased the yield attributes and yield of barley from 50\% RDN to $100 \%$. Application of $100 \%$ RDN also improves the $\mathrm{B}: \mathrm{C}$ ratio. Inoculation of Biomixrecorded significantly higher yield attributes viz. effective tillers $\mathrm{m}-2$, number of grains per spike and test weight. Grain and biological yield were recorded highest under Biomixtreatment. Higher net returns and $\mathrm{B} / \mathrm{C}$ ratio were also obtained with the application of Biomix in barley crop.

\section{References}

1. Anonymous 2018. USDA Circular Series WAP 7-18.

2. Alghabari F and SG Al-Solaimani. 2015. Effect of sowing date \& nitrogen fertilization on growth, yield \& yield components of barley (Hordeum vulgare L.). International Journal of Innovation \& Scientific Research 18: 136-140.

3. Anonymous 2014-15. Progress report of All India coordinated wheat and barley improvement project 2013-14. V(6). Barley Network, Directorate of Wheat Research, Karnal, India.
4. Anonymous 2016. Neresletter, Indian Institute of Wheat \& Barley Research 10(2): 1-1.

5. Behera UK and SK Rautaray. 2010. Effect of biofertilizers \& chemical fertilizers on productivity \& quality parameters of durum wheat (Triticum turgidum) on a vertisol of central India. Archives of Agronomy \& Soil Science 56(1): 65-72.

6. Chakrawarti VK and KP Kushwaha. 2006. Effect of sowing time, nutrients concentration \& uptake on yield maximization of barley (Hordeum vulgare L.). Progressive Agriculture 6(2): 194-196.

7. Dhiman S and YP Dubey. 2017. Effect of biofertilizers and inorganic fertilizers on yield attributes, yield and quality of Triticum aestivum and Zea mays in an acid alfisol. International Journal of Current Microbiology and Applied Sciences 6(7): 2594-2603.

8. Singh KP, PC Chaplot, HK Sumeria and GL Chaudhary. 2016. Performance of single-cut forage sorghum genotypes to fertility levels. Forage Research 42(2): 140-142.

9. Sunil K, RK Aggarwal, AK Dixit, AK Rai and SK Rai. 2012. Forage crops and their management. Indian Grassland and Fodder Research Institute 1-1.

10. Saraswati R and Sumarno. 2008. Application of soil microorganisms as component of agriculture technology. Iptek Dibidang Pangan 3: 41.

11. Singh J, SS Mahaland, A Singh. 2013. Productivity \& quality of malt barley (Hordeum vulgare) as affected by sowing date, rate \& stage of nitrogen application. Indian Journal of Agronomy (58): 72-80.

12. Javaheri M, AH Shiranirad, J Daneshian, E. Amiri and S Saifzadeh. 2014. Evaluation of chemical and organic nitrogen sources on yield and yield component of canola (Brassica napus L.) cultivars. International Journal of Biosciences (5): 47-54.

13. Kennedy IR, ATMA Choudhury and ML Kecskes. 2004. Non-symbiotic bacterial diazotrophs in cropfarming systems: can their potential for plant growth promotion be better exploited? Soil Biology \& Biochemistry 36(8): 1229-1244.

14. Nega Y, A Abraha and G Samuel. 2015. Interaction effects of inorganic $\mathrm{N}$-fertilizer \& seed rates on yield \& quality traits of malt barley varieties in the highland of tigray, north Ethiopia. Journal of Natural Sciences Research 5(13): 157-164. 
15. Kumar M, RK Pannu, B Singh and AK Dhaka. 2017. Response of irrigation frequency \& nitrogen levels on relative water content, canopy temperature, water potential \& chlorophyll content of late sown wheat. International Journal of Pure \& Applied Bioscience 5(2): 173-179.

16. Panwar AS, NP Singh, DC Saxena and UK Hazarika. 2006. Yield and quality of groundnutseed as influence by phosphorus, biofertilizer and organic manures. Indian Journal of Hill Farming (CAB abstracts).

17. Chaturvedi S and AS Chandel. 2005. Influence of organic \& inorganic fertilization on soil fertility \& productivity of soybean. Indian Journal of Agronomy 50(4): 311-313.

18. Chakrawarti VK andKP Kushwaha. 2006. Effect of sowing time, nutrients concentration \& uptake on yield maximization of barley (Hordeum vulgare L.). Progressive Agriculture 6(2): 194-196.

19. Nisha R, A Kaushik and CP Kaushik.2007. Effect of indigeneouscynobacterial application on structural stability and productivity of an organically poor semiarid soil. Geoderma 138(1-2): 49-56.

20. Yadav DD, CK Verma, BP Singh and S Shanker. 2011. Role of biofertilizers in relation to nitrogen levels on growth \& yield of wheat (Triticum aestivum L.). Crop Research 42 (1, 2 \& 3): 23-26.

21. Saraswati R and Sumarno. 2008. Application of soil microorganisms as component of agriculture technology. Iptek. Tan. Pangan 3:41.
22. Shirinzadeh A, H Soleimanzadeh and Z Shirinzadeh 2013. Effect of seed priming with plant growth promoting rhizobacteria (PGPR) on agronomic traits \& yield of barley cultivars. World Applied Sciences Journal 21(5): 727-731.

23. Yadav SM, R Singh, H Kumar, N Khan, SP Verma, Shweta, BK Yadav and S Kumar. 2014. Response of late shown wheat (Triticum aestivum) to FYM, biofertilizers \& inorganic nitrogen alone and in different combinations. Plant Archives 14(2): 1127-1129.

24. Singh, RR andK Prasad. 2011. Effect of bio-fertilizers on growth \& productivity of wheat (Triticum aestivum). Journal of Farm Sciences 1(1): 1-8.

25. Thalooth T, A Bahr and MM Tawfik 2012. Productivity of some barley cultivars as affected by inoculation under water stress conditions. Applied Botany 51: 10743-10749.

26. Shevananda. 2008. Influence of bio-fertilizers on the availability of nutrients ( $\mathrm{N}, \mathrm{P}$ and $\mathrm{K}$ ) insoil in relation to growth and yield of Stevia rebaudiana grown in South India. International Journal of Applied Research in Natural Products 1(1): 20-24.

27. Yadav SM, R Singh, H Kumar, N Khan, SP Verma, Shweta, BK Yadav and S Kumar. 2014. Response of late shown wheat (Triticum aestivum) to FYM, biofertilizers\& inorganic nitrogen alone and in different combinations. Plant Archives 14(2): 1127-1129. 